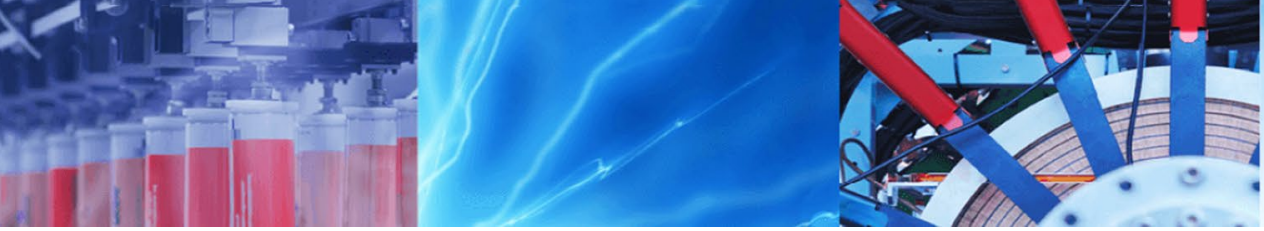

Research Article

\title{
Residual load carrying capacity of reinforced concrete cylinders after heating at elevated temperature
}

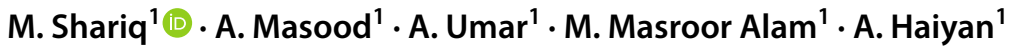

Received: 1 March 2020 / Accepted: 2 September 2020 / Published online: 11 September 2020

(c) Springer Nature Switzerland AG 2020

\begin{abstract}
The present research work is investigating the behavior of reinforced concrete (RC) cylinders after exposure to elevated temperatures. Reinforcement was done by using the longitudinal bars with closely spaced lateral ties (i.e. confinement). Experiments were carried out on the RC cylinders subjected to a single heating-cooling cycle of elevated temperature ranging from 200 to $800^{\circ} \mathrm{C}$ with an interval of $200^{\circ} \mathrm{C}$ for a holding time of $3 \mathrm{~h}$. The crack patterns, color change, spalling and residual load carrying capacity of RC cylinders after exposure to elevated temperature have been observed. The residual load carrying capacity of RC cylinders has been compared with the load carrying capacity of control specimens at ambient temperature. The percent reduction in residual load carrying capacity after heating at $200^{\circ} \mathrm{C}, 400^{\circ} \mathrm{C}, 600^{\circ} \mathrm{C}$, and $800{ }^{\circ} \mathrm{C}$ temperature is $24.5 \%, 38.8 \%, 63.3 \%$, and $83.7 \%$ respectively as compared with the load carrying capacity at ambient temperature. The finite element modeling (FEM) has been carried out to observe the thermal stresses and strains induced in the confined RC cylinders. Experimental observations of thermal strains and those obtained by the numerical model showed a good agreement. The scanning electron microscopy (SEM) has also been carried out to study the changes in the microstructure of confined high grade concrete and it was observed that the micro-cracks and pores increase and become more pervasive with increase in temperature.
\end{abstract}

Keywords Reinforced concrete · Confinement · Elevated temperature · Residual load capacity · Finite element modeling $\cdot$ Scanning electron microscopy

\section{Introduction}

Generally, the structural members of reinforced concrete (RC) buildings are at ambient temperature during the construction phase and the life span of the structure. But, sometimes the structural members are subjected to high temperatures such as fire due to accidental, fire due to malfunctioning of electrical equipment, fire incombustible material, and gas explosion. Now due to the massive growth of multistory concrete buildings, the design of structural members should satisfy the safety and serviceability requirements along with the fire safety provisions for the buildings. Judicious selection of construction material for multistory RC building is also important so that a building should not suffer severe deterioration or complete gutting during the fire due to sudden loss of strength. When a fire occurs in a building, the temperature increases, non-uniform temperature field forms, and the material used in structure deteriorate due to differential coefficient of thermal expansion of reinforcement, cement, fine and coarse aggregate, causing damage and strength reduction at different levels in the structure. The use of high grade concrete (HSC) in multistory buildings (mainly in columns) can play a significant role in the structural

$\triangle$ M.Shariq, mshariq.cv@amu.ac.in; mshariqdce@gmail.com; A. Masood, a.masood.cv@amu.ac.in; A.Umar, arshad_umar@rediffmail.com; M. Masroor Alam, mmalam.cv@amu.ac.in; A. Haiyan, haiyanabu@gmail.com | 'Department of Civil Engineering, Aligarh Muslim University, Aligarh 202001, India. 
performance of the multistory buildings. But, spalling in high-grade concrete columns at elevated temperature is a serious problem that can affect the safety and serviceability of columns during the fire as well as during retrofitting.

The past research mainly involved investigations on the characteristics of materials such as constituting relationships of unconfined (i.e. without ductile detailing) and confined HSC, the behavior of concentrically loaded HSC columns, and the response of HSC columns under axial load at ambient and elevated temperature. Raut and Kodur [1] proposed a macroscopic finite element model for tracing the fire response of reinforced concrete (RC) columns. The analytical results were compared with the experimental data and found reasonable accuracy. AlSalloum et al. [2] investigated the behavior of externally confined concrete with FRP sheets subjected to $100^{\circ} \mathrm{C}$ and $200{ }^{\circ} \mathrm{C}$ temperature for a period of 1,2 , and $3 \mathrm{~h}$. They concluded that the marginal loss of strength at $100^{\circ} \mathrm{C}$ temperature resulting only the melting of epoxy coating and this loss was more pronounced at $200^{\circ} \mathrm{C}$. Kumar et al. [3] studied the pre-damaged concrete specimens exposed to temperature upto $900{ }^{\circ} \mathrm{C}$. It was concluded that the no spalling and any thermal cracking was observed in the pre-damage confined concrete when heated up to $600{ }^{\circ} \mathrm{C}$ and few thermal cracks were observed at $900^{\circ} \mathrm{C}$. Ramadoss and Nagamani [4] carried out experiments to investigate the stress-strain behavior of high-performance steel fiber reinforced concrete (HPSFRC) in compression with compressive strength of 52-80 MPa. Based on the experimental data, a simple model for the stress-strain relationship for HPSFRC is proposed and found in good agreement with the experimental data. $\mathrm{Wu}$ and $\mathrm{Wu}$ [5] studied the effect of heating exposure from 1 to $6 \mathrm{~h}$ with an interval of $1 \mathrm{~h}$ on the residual compressive strength of concrete. Standard cylindrical specimens were heated at elevated temperatures ranging from 100 to $600{ }^{\circ} \mathrm{C}$ were then tested under compression. It was concluded that the 3-hour heating is not influencing the residual compressive strength at elevated temperature. Su et al. [6] observed that the dynamic compressive strength increases with an increase in strain rate at all temperatures. Ma et al. [7] critically reviewed the mechanical properties of concrete subjected to high temperature. It was concluded that the detrimental effects at the structural level may be due to the spalling of concrete subjected to high temperature. Khan and Abbas [8] investigated the effect of elevated temperature on four types of concrete mixes exposed up to $700{ }^{\circ} \mathrm{C}$ for $1,2,3$, and $7 \mathrm{~h}$ heating periods. After heating the concrete specimens containing $5 \%$ SF and 10\% GGBFS do not show any sign of cracks up to peak temperature. Lee et al. [9] observed that the strength reduction in high strength concrete is increased with higher compressive strength of concrete subjected to elevated temperature.
Yermak et al. [10] concluded that the steel fibers control the propagation of cracks and reduce the stress relaxation and new pores in the concrete subjected to high temperature. Zahid et al. [11] observed the compression behavior of the RC column after $2 \mathrm{~h}$ heating at $600^{\circ} \mathrm{C}$ temperature. They found that the load carrying capacity was affected at elevated temperature due to the loss of water from the column specimen.

Ibrahimbegovic et al. [12] carried out the statistical data review on the causes and damage of concrete and reinforced concrete when exposed to fire. They also presented the experimental approaches for the fire resistance to concrete and reinforced concrete. Based on their statistical and experimental reviews, they developed models for the assessment of fire induced damage in concrete and reinforced concrete structures. Al-Salloum et al. [13] developed the neural network models for the prediction of compressive strength of normal and high strength concrete containing. Two models were developed by considering two variables i.e. raw variables and grouped dimensionless variables. The quantities of cement, fine aggregate, coarse aggregate, micro-silica, water and super-plasticizer, the maximum size of coarse aggregate, fineness modulus of fine aggregate were the variables for compressive strength models. The neural network models were trained and tested by using available experimental data and then compared with regression models. They concluded that neural network models are more practical and beneficial. Shrestha et al. [14] provided the finite element model of FRP for strengthening of beam-column connections. They concluded that the finite element analysis is capable to model the failure behavior of FRP. Rashid and Aboutaha [15] developed the confined concrete model for CFRP circular RC column at elevated temperature. Tensile strength and modulus of CFRP at elevated temperature and their effect on concrete confinement were the main parameters for the confined concrete model. Mohamed [16] used the data of experimentally tested specimens to verify a numerical finite element model developed and observed that experimental measurements and numerical results showed a good agreement. The numerical model was used to cover a wider range of concrete characteristic strengths and with the different heating processes. Results showed that there is a slight reduction in the load carrying capacity in unheated lightweight columns when compared to that of normal-weight concrete columns. Wu and Wang [17] developed the multi-scale model for the prediction of circular column strength subjected to longitudinal compressive load. The predicted strength from the proposed model is found in good agreement with the available experimental. Buch and Sharma $[18,19]$ conducted experiments on the RC column subjected to fire and developed an empirical model to predict the behavior of RC columns 
under fire. Chinthapalli and Agarwal [20] studied the effect of confinement on the behavior of axially loaded RC columns under compression subjected to elevated temperature. The experimental results were simulating numerically and found good agreement.

The major objectives of the past studies are the role of various types of confinement and the validity of applying the current building code requirements to the case of high-grade concrete specimens. The past studies show that the use of confinement and high-grade concrete in RC members in multistory buildings subjected to elevated temperature can provide a safety solution for a sufficient duration of time. Literature pointed out that the focus on the materials properties should be given on the effect of testing methodology, duration of heating and heating rate of elevated temperature. Literature also indicates that more experimental investigations are needed on the high grade concrete to simulate the better results for the modeling and design of $\mathrm{RC}$ structures with the consideration of spalling of concrete at elevated temperature. Therefore, in the present research work, the experimental and analytical investigation has been planned on the residual load carrying capacity of confined high grade RC cylinders subjected to single heating cooling cycle of elevated temperature. Following are the objectives of the present research work:

- To study the effect of ambient and higher temperatures $\left(200^{\circ} \mathrm{C}, 400^{\circ} \mathrm{C}, 600^{\circ} \mathrm{C}\right.$, and $\left.800^{\circ} \mathrm{C}\right)$ on the physical, mechanical, and micro properties of RC cylinders subjected to single heating-cooling cycle.

- To compare the experimental results obtained at ambient and higher temperature with the results obtained from finite element analysis using ANSYS.

- To study the micro properties of high grade concrete at higher temperatures by scanning electron microscopy.

\section{Experimental program}

\subsection{Material properties}

The 43 grade of Ordinary Portland Cement (OPC) with the commercially available micro silica fume (SF) of grade $920 \mathrm{U}$ (silica content of more than 92\%) was used for the development of concrete strength greater than $60 \mathrm{MPa}$. The properties of OPC and SF satisfied the requirement of IS: 4031 [21] and IS 15388 [22] respectively. Locally available river sand with fineness modulus $(F M)=2.83$, specific gravity $=2.63$ and water absorption $=0.8 \%$ was used as fine aggregate $(F A)$ and crushed granite stone of maximum size of $10 \mathrm{~mm}$ with $\mathrm{FM}=8.0$, specific gravity $=2.63$ and water absorption $=0.4 \%$ was used as coarse aggregate (CA). The properties of these aggregates satisfied the requirement of IS: 383 [23]. Thermo-mechanical treated (TMT) steel bars of $6 \mathrm{~mm}$ nominal diameter were used as reinforcement for concrete specimens. The properties of reinforcement bars confirmed to IS 1786 [24]. The measured yield strength of longitudinal and lateral ties was $486 \mathrm{MPa}$. The potable water was used for mixing and curing which was free from deleterious materials as recommended by IS: 456 [25]. The commercially available superplasticizer, CONSFLO S, which is based on carboxylic ether polymer, was used.

Method of trials was used for the development of highgrade concrete mix at ambient temperature conditions. The high grade concrete mix for RC specimens was cement content $=600 \mathrm{~kg} / \mathrm{m}^{3}$, silica fume $=49.8 \mathrm{~kg} / \mathrm{m}^{3}$, fine aggregate $=624 \mathrm{~kg} / \mathrm{m}^{3}$, coarse aggregate $=1050 \mathrm{~kg} / \mathrm{m}^{3}$, water to cement ratio $=0.30$ and dosage of superplasticizer by weight of cement $=1.5 \%$. The $30 \mathrm{~mm}$ slump was maintained for the concrete mix used in the present study. The measured 28 days cylinder $(150 \times 300 \mathrm{~mm})$ compressive strength of high-grade concrete mix was $49.6 \mathrm{MPa}$.

\subsection{Casting and curing of specimens}

Special cylindrical moulds of $100 \times 450 \mathrm{~mm}$ (diameter $\times$ height) in size were fabricated in the laboratory for making RC cylindrical specimens. The specimens are reinforced with $6 \# 6 \mathrm{~mm}$ diameter bars as longitudinal reinforcement ( 2.16 percent steel) and 5 \# $6 \mathrm{~mm}$ circular lateral ties for the spacing of longitudinal bars and for confinement as shown in Fig. 1. The concrete was poured in the cylindrical moulds in such a manner that a thick layer of concrete was prepared for making the cover to

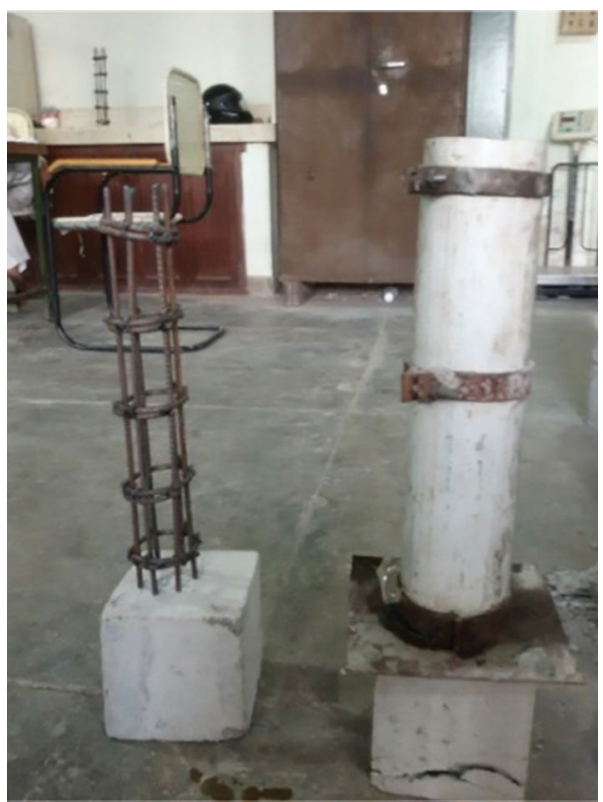

Fig. 1 Reinforcement detailing in cylindrical specimen 
the reinforcement and vibrated for half a minute. On this cover, the cage of reinforcement was placed with equal side cover as shown in Fig. 1. The remaining material was poured in the mould and compacted in three layers and vibrated for half a minute. The top surface of the specimen was leveled and made uniform and smooth. The specimens were demoulded after $24 \mathrm{~h}$ and cured underwater for 28 days. After 28 days of curing, the specimens were prepared for testing at ambient and elevated temperatures.

\subsection{High temperature furnace for testing of RC specimens at elevated temperature}

The electric furnace shown in Fig. 2 was fabricated for testing of concrete specimens at different thermal loading. The heating elements were fixed at the two opposite sides and on the top side of the furnace, with refractory lining on all six faces. The internal dimensions of the furnace are $1000 \times 760 \times 510 \mathrm{~mm}$ (length $\times$ width $\times$ height) and the electric furnace has the rating of $1150^{\circ} \mathrm{C}$. After curing, the specimens were heated at elevated temperatures i.e. at $200{ }^{\circ} \mathrm{C}, 400{ }^{\circ} \mathrm{C}, 600{ }^{\circ} \mathrm{C}$, and $800{ }^{\circ} \mathrm{C}$ for one single heating-cooling cycle under unstressed condition. After reaching the target temperature $(\mathrm{T})$ at a heating rate of $5{ }^{\circ} \mathrm{C}$ per minute, the specimens were heated for $3 \mathrm{~h}$ heating duration (i.e. holding time) keeping in view that concrete must have a fire test rating of at least $2 \mathrm{~h}$ to ensure that structural damage will not result in a collapse, and safety of firefighters can be ensured. Public life-safety codes do not allow structures to be built unless they have $2 \mathrm{~h}$ of fire ratings and insurance companies will not insure structures that have less than $2 \mathrm{~h}$ of fire rating [26]. The furnace was completely closed during the heating and cooling process. Figure 2 also shows the details of one single heating-cooling cycle up to the target temperature.

After the successive single heating-cooling cycle of each elevated temperature, the behavior of concrete specimens such as color change and development of cracks and spalling has been observed. Then the specimens have been tested under the compression testing machine as shown in Fig. 3 for residual load carrying capacity according to IS: 516 [27] and the average reading of five specimens has been reported. The temperature

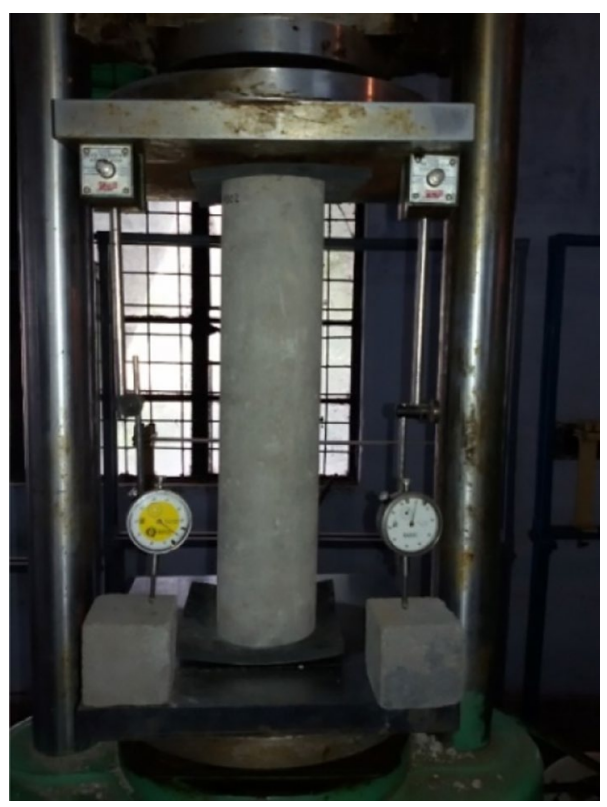

Fig. 3 Testing of RC specimen under compression
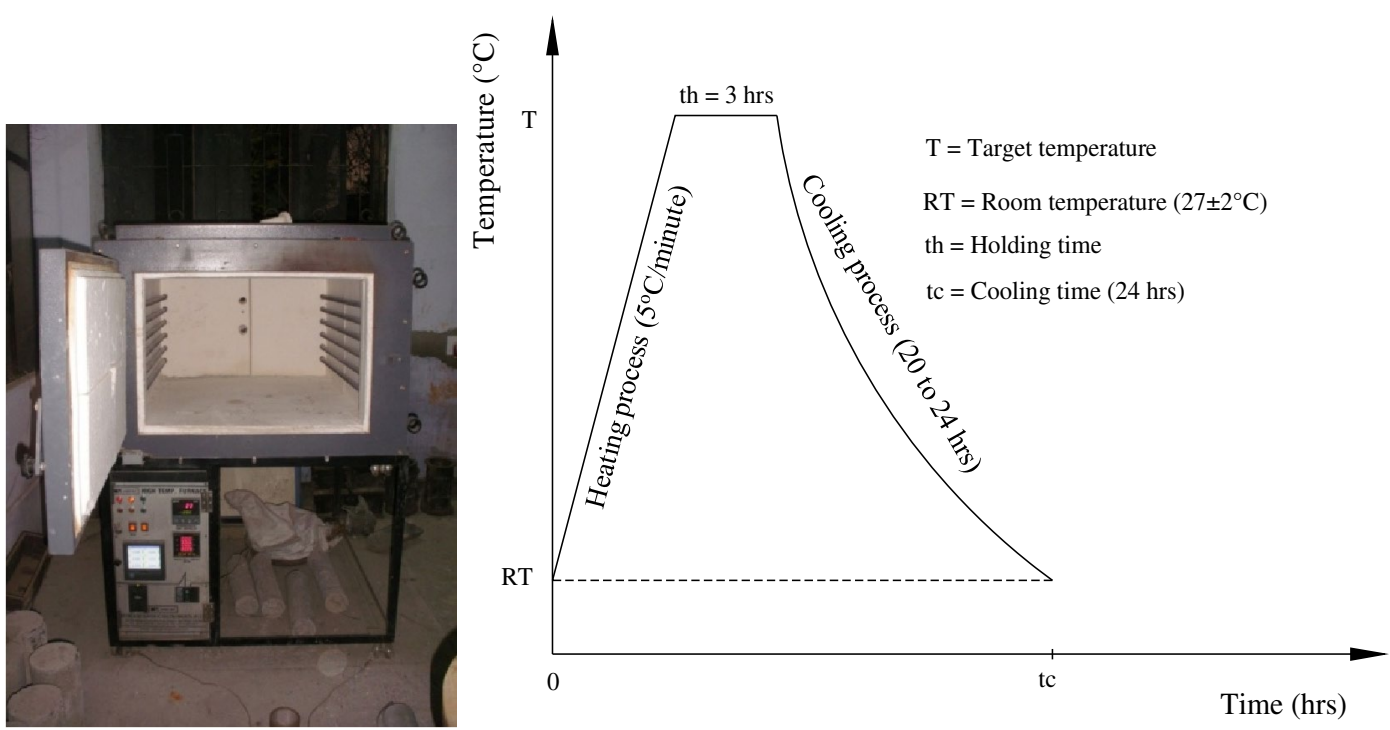

Fig. 2 Details of high temperature furnace and heating-cooling cycle curve

\section{SN Applied Sciences}


difference between the furnace temperature and concrete temperature was measured separately with the help of thermocouples. The ratio between inside concrete temperature and furnace temperature was $0.66,0.84,0.93$ and 0.87 at $200{ }^{\circ} \mathrm{C}, 400^{\circ} \mathrm{C}, 600{ }^{\circ} \mathrm{C}$ and $800^{\circ} \mathrm{C}$ respectively. The stress-strain behavior of RC cylinders at high temperature has been plotted. Scanning electron microscopy has also been carried out on tested specimens undergone heating and compression at different temperatures.

\section{Results and discussion}

\subsection{Physical observations}

The induction of colour change in concrete is associated with maximum exposed temperature and loss in mechanical properties. In the present study, the concrete is made with granite as coarse aggregate exposed to different elevated temperatures. The colour sequence has been observed is actual. It has been observed that the colour of concrete is medium mottled gray as per our mix of cement, sand, and aggregate. Once concrete specimens are heated in our experiment it became a lighter and lighter version of mottled creamy peach gray up to $600^{\circ} \mathrm{C}$ and finally takes a very light whitish-gray colour at $800^{\circ} \mathrm{C}$.

The development of cracks on concrete specimens after heating at elevated temperatures ranging from 200 to $800^{\circ} \mathrm{C}$ at an interval of $200^{\circ} \mathrm{C}$ is shown in Fig. 4. With the increase in temperature, the cracks in the high grade of concrete specimens started from the corners towards the interior parts of the specimen. After heating at $200^{\circ} \mathrm{C}$ temperature, only few micro-cracks on the surface of the specimens have been observed. After the exposure of $400{ }^{\circ} \mathrm{C}$ temperature, the surface of the entire specimen has been covered with hairline cracks network. With further increase in temperature from 400 to $600{ }^{\circ} \mathrm{C}$, these hairline cracks were further expanded with considerable depth. After heating at $800^{\circ} \mathrm{C}$, plentiful cracks on the surface especially at the edges of the specimens have been observed and the cracks are more invasive. The probable reason for cracking in a high grade of concrete specimens may be due to the thermal expansion of cement paste due to the insufficient growth of $\mathrm{C}-\mathrm{S}-\mathrm{H}$ crystals at high temperature, causing bond failure between the cement and the aggregate. Further, when the exposed temperature rises, drying shrinkage eventually becomes much greater than thermal expansion as water is driven off. These two opposing actions progressively weaken the bond and hence cracking the concrete.

The probability of spalling depends upon the number of factors such as high moisture content, rapid increases in cross-section temperature, high slenderness ratios,

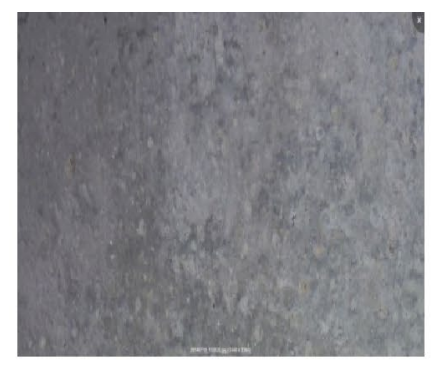

At room temperature

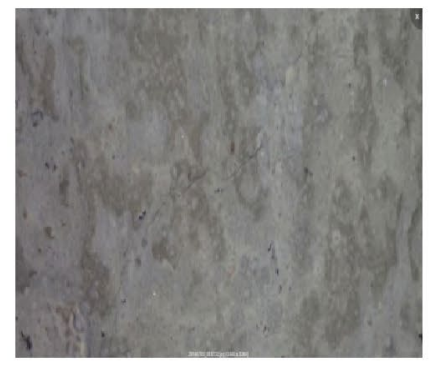

At $200^{\circ} \mathrm{C}$

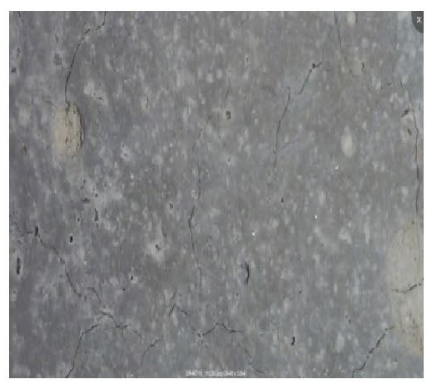

At $400^{\circ} \mathrm{C}$

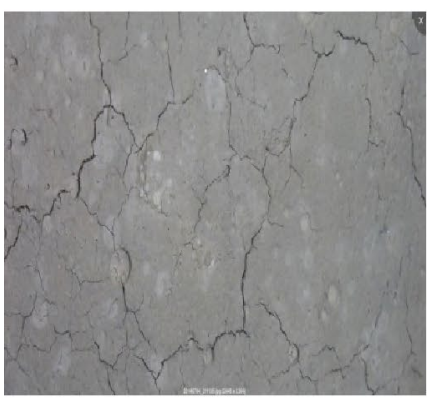

At $600^{\circ} \mathrm{C}$

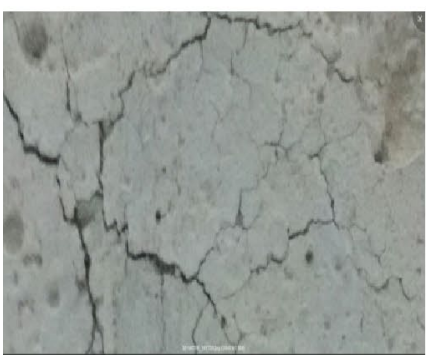

At $800^{\circ} \mathrm{C}$

Fig. 4 Cracks formation on confined RC specimens at elevated temperatures

and large concrete stresses. In the present research work, the spalling in the confined RC specimen has not been observed may be due to a slower rate of increase in temperature and lower slenderness ratio. Further, the closely spaced lateral ties (i.e. confinement) are also likely to 
protect against spalling. Therefore, only surface splitting of concrete has been observed on the specimens subjected to $800^{\circ} \mathrm{C}$ temperature. The physical observations made on the concrete specimens at ambient and after exposure to elevated temperature is shown in Table 1.

\subsection{Effect of single heating-cooling cycle on residual strength of $\mathrm{RC}$ specimens}

The residual load carrying capacity of high grade RC cylinders after exposure to elevated temperature is shown in Fig. 5a. In this figure, the effect of elevated temperatures on the load carrying capacity of RC specimens is visible. It can be seen that the load carrying capacity of RC specimens decreases with increase in temperature from ambient to $800^{\circ} \mathrm{C}$. The percent reduction in residual load carrying capacity after heating at $200^{\circ} \mathrm{C}, 400{ }^{\circ} \mathrm{C}, 600^{\circ} \mathrm{C}$, and $800{ }^{\circ} \mathrm{C}$ temperature is $24.5 \%, 38.8 \%, 63.3 \%$, and $83.7 \%$ respectively as compared to load carrying capacity at ambient temperature. The reason for decrease in compressive strength at higher temperature may be attributed to the bond failure between concrete and steel. Similar

Table 1 Physical observations of reinforced high grade of concrete specimen at elevated temperature

\begin{tabular}{llllll}
\hline Characteristics & \multicolumn{5}{l}{ Temperatures $\left({ }^{\circ} \mathrm{C}\right)$} \\
\cline { 2 - 6 } & AT & 200 & 400 & 600 & 800 \\
\hline Color & G & LG & WG & WG & C \\
Crack analysis & N & M & H & M and D & S \\
Spalling & - & NS & NS & NS & SS \\
\hline
\end{tabular}

Symbols for color $G$ grey, LG light grey, WG whitish grey, C creamy Symbols for cracking $N$ no cracks, $m$ micro cracks, $m$ micro cracks, $H$ hairline cracks, $M$ macro cracks, D deeper cracks, $S$ severe deeper cracks

Symbol of spalling NS no spalling, SS surface splitting

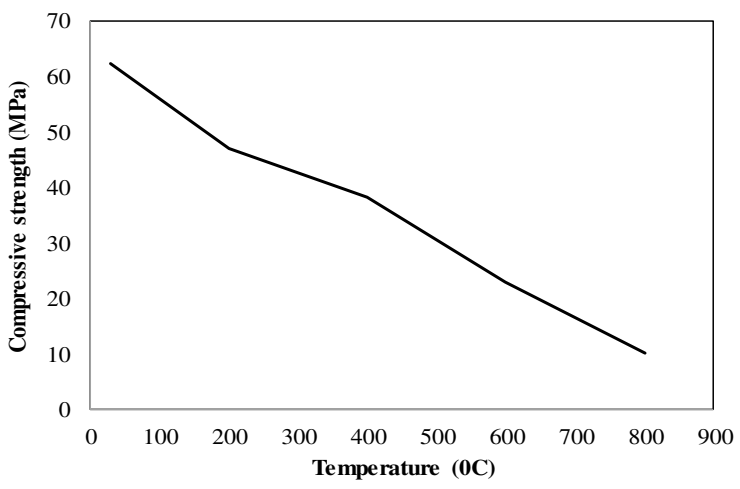

(a) Residual load carrying capacity observations were also made in past researches [11, 28]. The stress-strain curves up to the ultimate load of confined high-grade RC specimen after heating at elevated temperature ranging from 200 to $800{ }^{\circ} \mathrm{C}$ is also shown in Fig. 5b. Each specimen was subjected to one single heating-cooling cycle up to the target temperature for a holding time of $3 \mathrm{~h}$. It can be seen from the figure that the strain significantly increases with increase in temperature. Furthermore, this behavior is greatly influenced by the amount of moisture present in the concrete before subjecting it to high temperature as well as the compressive strength of the concrete at ambient temperature [29]. Although the moisture content has not been measured in this work and the effect of concrete compressive strength was not part of the study. It has been observed that at $400{ }^{\circ} \mathrm{C}$, the strains are half of that observed at $800^{\circ} \mathrm{C}$. It has also been observed that at each of the thermal loading from 200 to $800^{\circ} \mathrm{C}$, the stiffness reduces along with the compressive strength of the RC specimen.

\subsection{Finite element modeling}

The finite element modeling is performed by using ANSYS to calculate the nodal elastic stresses, induced by mechanical constraints and thermal strains. A three-dimensional eight nodded tetrahedral element having thermal degreeof-freedom (element type Plane 55) is chosen for the heat conduction problem. A solid reinforced concrete specimen model shown in Fig. 6 a is discretized with a 2D finite element model used for the thermal analysis of the confined high-grade concrete specimen. The thermal version of the model was used to calculate the temperature profile in the RC specimen and the structural version of the model then read the temperature profile to calculate stresses. The distributions of thermal elastic stress components were then calculated by switching the plane 55 thermal elements to plane 183 structural elements which are used

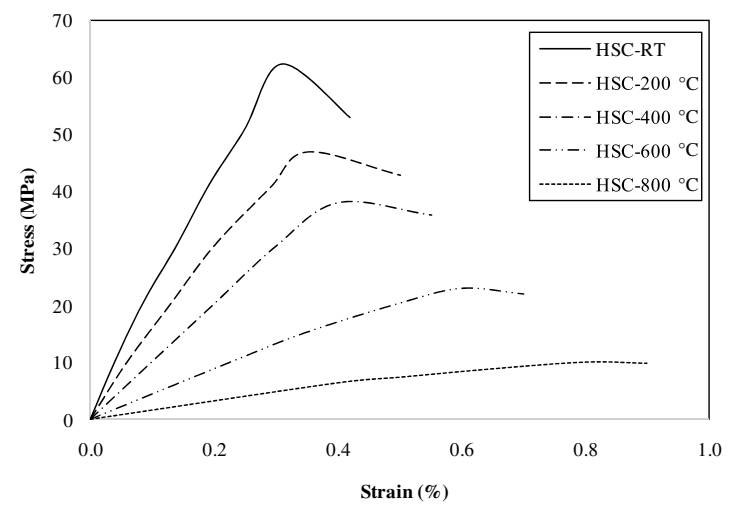

(b) Stress-strain curve

Fig. 5 Residual load carrying capacity and stress-strain behavior of RC cylinders after exposure to elevated temperature 


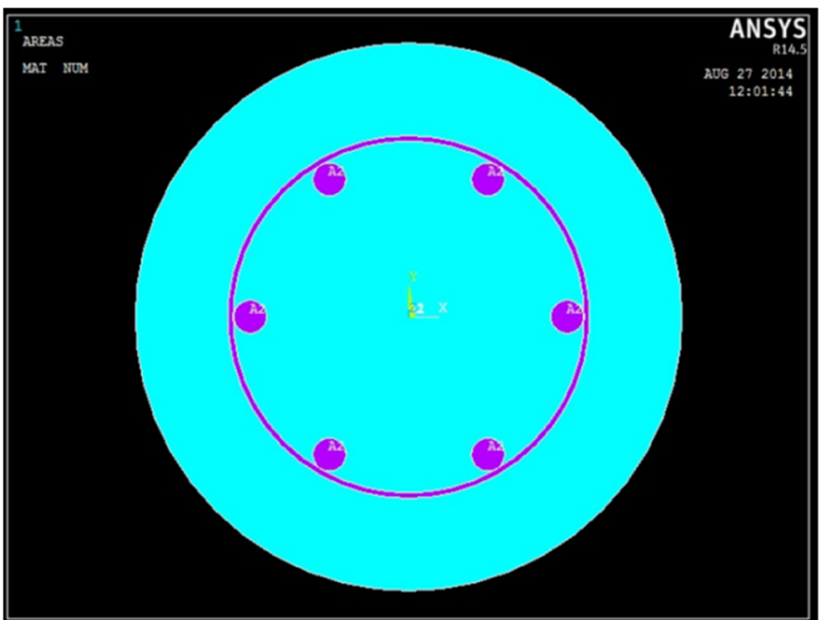

(a) RC model used for the thermal analysis

Fig. 6 Finite element model and meshing of RC cylindrical specimens

Table 2 Temperature field in the FE model subjected to elevated temperature

\begin{tabular}{lll}
\hline $\begin{array}{l}\text { Temperature at } \\
\text { the surface }\end{array}$ & $\begin{array}{l}\text { Temperature at the } \\
\text { center after } 1 \mathrm{~h} \text { heating }\end{array}$ & $\begin{array}{l}\text { Temperature at } \\
\text { the center after } 3 \mathrm{~h} \\
\text { heating }\end{array}$ \\
\hline $200^{\circ} \mathrm{C}$ & $146^{\circ} \mathrm{C}$ & $199^{\circ} \mathrm{C}$ \\
$400{ }^{\circ} \mathrm{C}$ & $292^{\circ} \mathrm{C}$ & $395^{\circ} \mathrm{C}$ \\
$600{ }^{\circ} \mathrm{C}$ & $438^{\circ} \mathrm{C}$ & $597{ }^{\circ} \mathrm{C}$ \\
$800^{\circ} \mathrm{C}$ & $584^{\circ} \mathrm{C}$ & $796{ }^{\circ} \mathrm{C}$ \\
\hline
\end{tabular}

for 2-D modeling of solid structures. Figure $6 \mathrm{~b}$ shows the finite element meshing of the RC cylinders. A single heating-cooling cycle of high temperatures was loaded and heated from room to the target temperatures. The simulation of the thermal transfer and the associated thermal stresses was carried out by using the thermal stress analysis available in the finite element code. The confined RC specimen so modeled gives stresses and strains and temperature contours.

From the FE analysis, it has been observed that the temperature on the surface of the model rises very quickly during heating at high temperature, but the temperature in the interior increases slowly. Therefore, the non-uniform temperature field is formed in the specimen, especially a large temperature gradient in the outer layer. Also, the temperature field varies continuously for the duration of the heating as shown in Table 2. Though high-grade concrete has low conductivity temperature at the center reaches about $70 \%$ of maximum temperatures after one-hour heating duration of the desired temperature. Figure 7 shows the temperature

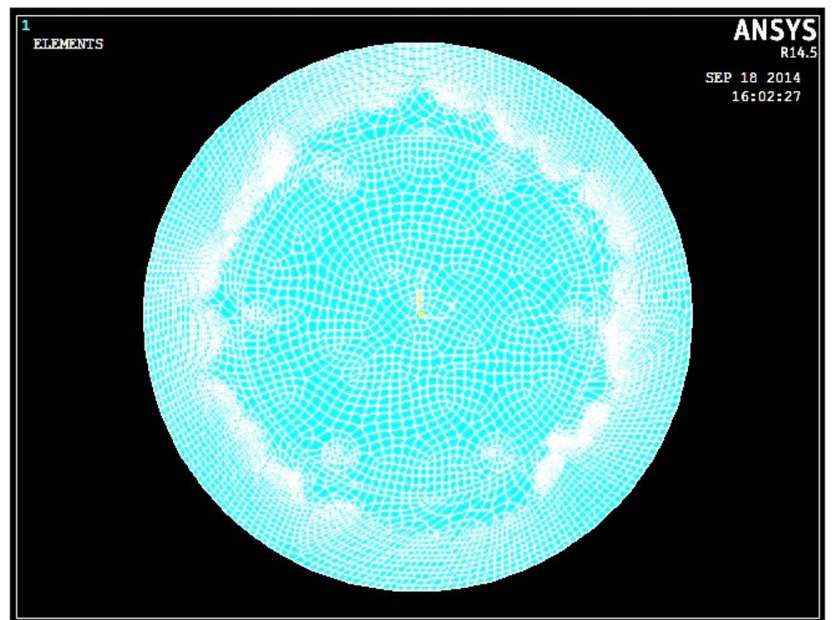

(b) Finite element of RC cylindrical specimen

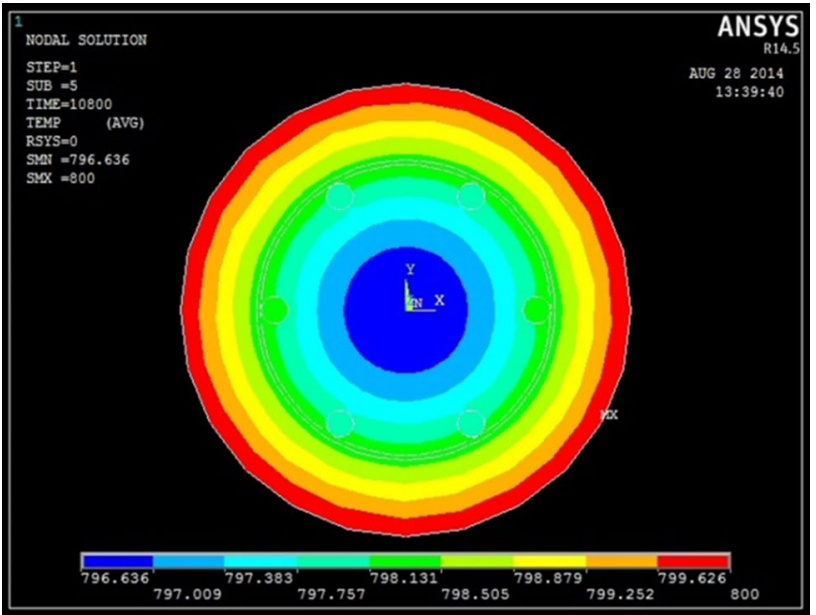

Fig. 7 Temperature contours at $800^{\circ} \mathrm{C}$ after $3 \mathrm{~h}$ heating duration

contours at $800^{\circ} \mathrm{C}$ after $3 \mathrm{~h}$ heating duration. Further, it has been observed that the deformation in the confined $\mathrm{RC}$ specimens increases with the increase in temperature from $27 \pm 2{ }^{\circ} \mathrm{C}$ to $800^{\circ} \mathrm{C}$. The initial deformation in the $\mathrm{RC}$ specimen was mainly due to the thermal expansion of concrete and steel. As the deformation of both materials increases at higher temperatures, the strength of the confined RC specimen at higher temperatures decreases considerably. This increase in deformation was due to increase in thermal stress due to the heating of the model at higher temperature. The experimentally observed thermal strains shown in Fig. 5 are in close agreement with the thermal strains shown in Fig. 8. 


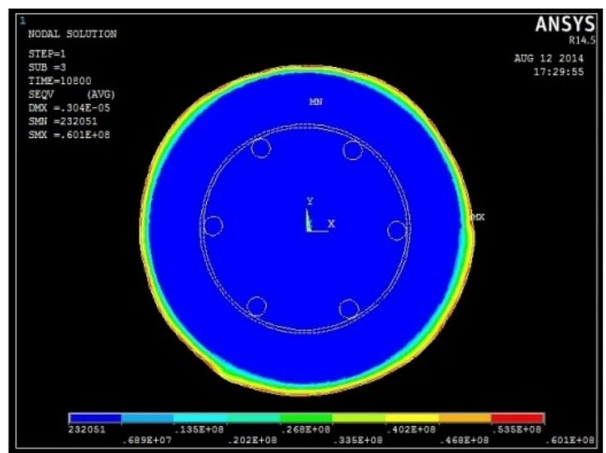

Thermal stress at $200^{\circ} \mathrm{C}$

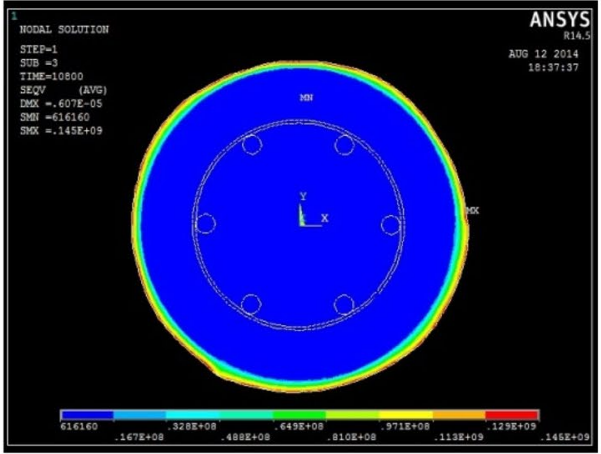

Thermal stress at $400^{\circ} \mathrm{C}$

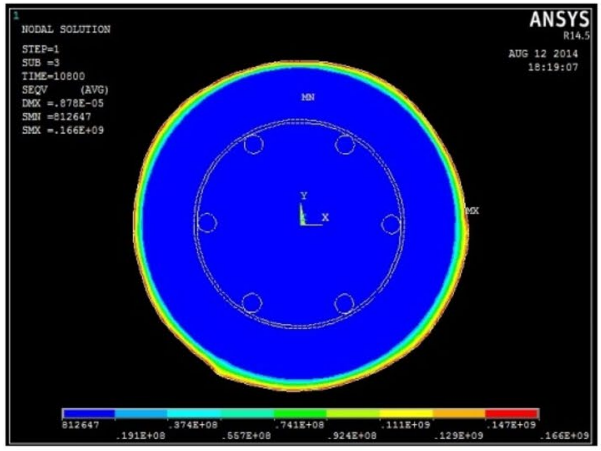

Thermal stress at $600^{\circ} \mathrm{C}$

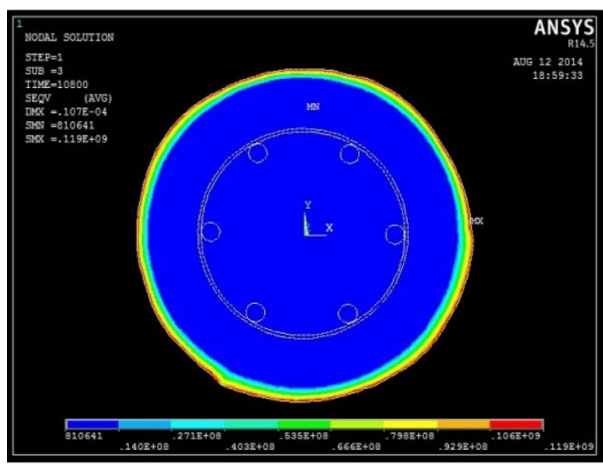

Thermal stress at $800^{\circ} \mathrm{C}$

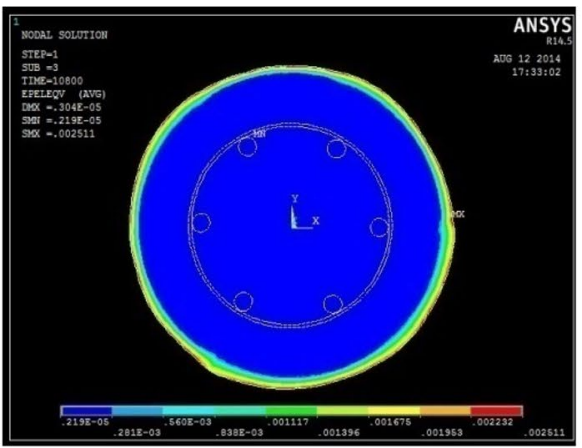

Thermal strain at $200^{\circ} \mathrm{C}$

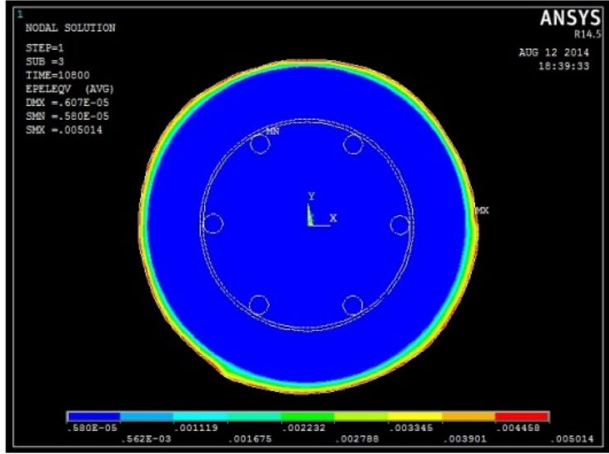

Thermal strain at $400^{\circ} \mathrm{C}$

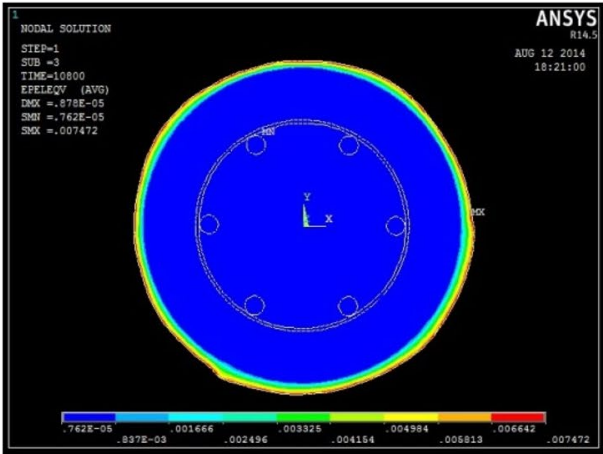

Thermal strain at $600^{\circ} \mathrm{C}$

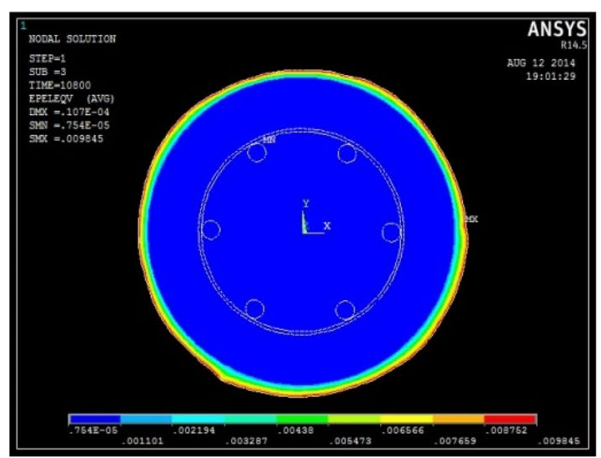

Thermal strain at $800^{\circ} \mathrm{C}$

Fig. 8 Thermal stress and strain development in confined RC specimen at elevated temperatures 


\subsection{Microscopic study}

Scanning electron microscopy (SEM) was carried out to study micro-texture of high grade reinforced concrete subjected to heating at different temperatures. The SEM has been used to see the effect of heating based on the change in micromorphology of the sand-cement matrix.
The SEM pictures of samples cured at room temperature were compared with those heated at higher temperatures. The observation focused on bonding between cement and sand matrix with the aggregates and on the micro-texture of the mortar matrix. The formation of $\mathrm{C}-\mathrm{S}-\mathrm{H}$ authigenic mineral phases as shown in Fig. 9a originating within cement during the hydration process and their changes
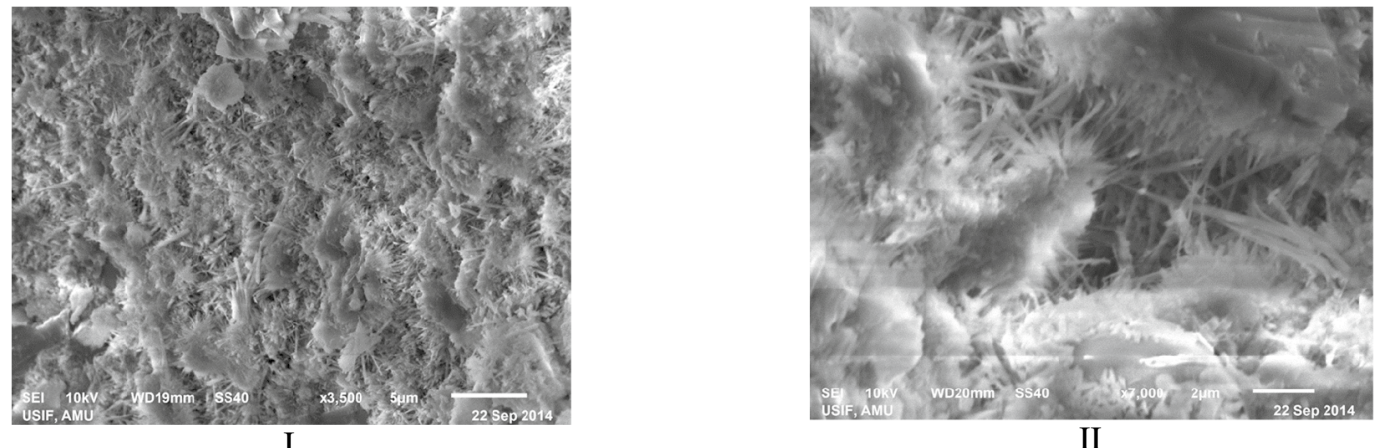

II

(a) SEM photomicrograph showing sand-cement matrix with well-developed C-S-H crystals, grown over the mineral grains of aggregate at room temperature. The calcium sulfo hydroxide $(\mathrm{C}-\mathrm{S}-\mathrm{H})$ is well developed seen at (I) $3500 \mathrm{X}$ and (II) $7000 \mathrm{X}$.
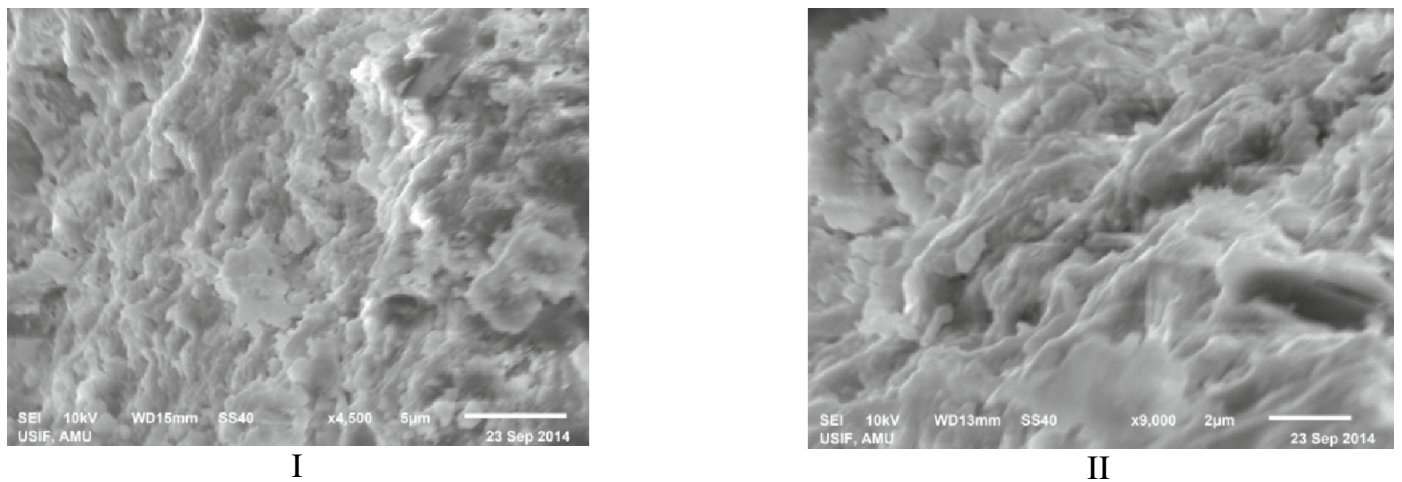

(b) SEM photomicrograph showing massive development of cement matrix at $200^{\circ} \mathrm{C}$, clinging over the mineral grains of aggregate seen at (I) $4500 \mathrm{X}$ and (II) $9000 \mathrm{X}$ magnification.
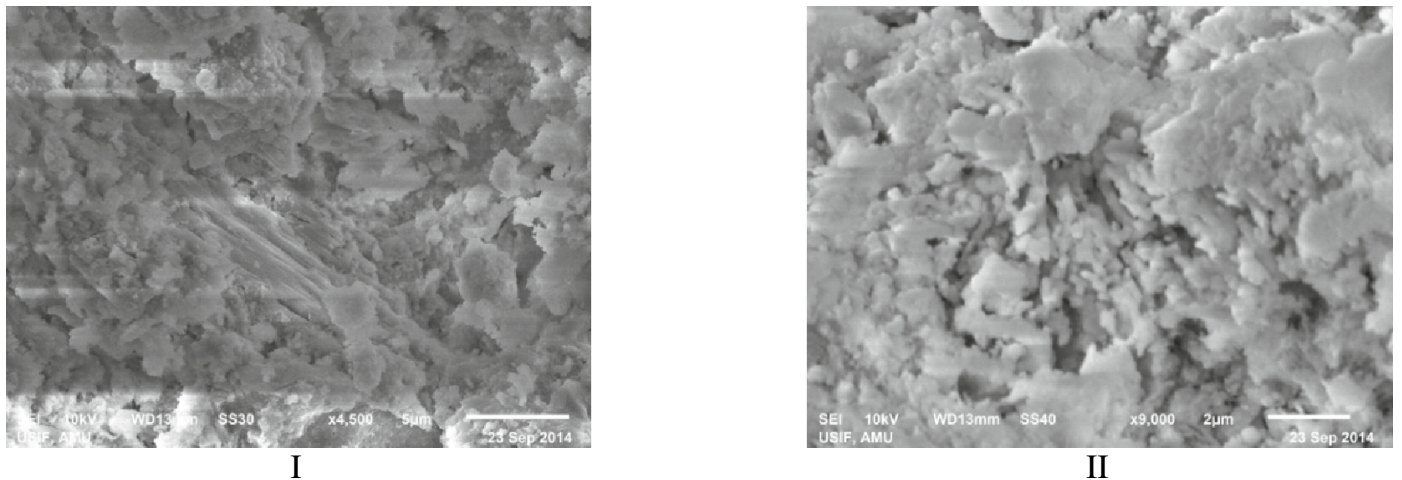

(c) SEM photomicrograph showing massive development of cement matrix at $400^{\circ} \mathrm{C}$, with the presence of micropores within the cement matrix (I) 4500X and (II) $9000 \mathrm{X}$ magnification.

Fig. 9 Microstructure of high grade of reinforced concrete specimens after exposure to elevated temperature 

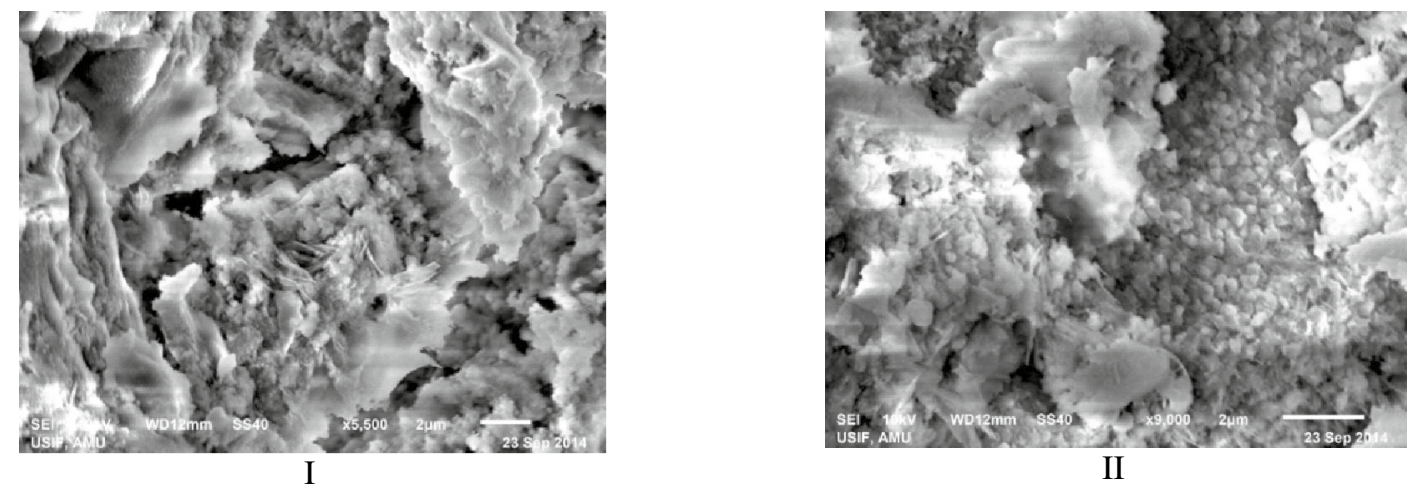

(d) SEM photomicrograph showing cement matrix clinging over the mineral grains of aggregate at $600^{\circ} \mathrm{C}$. The micro-texture at this temperature has become open with the development of calcium aluminate and fibrous growth of calcium sulfo hydroxide seen at (I) 5500X and (II) $9000 \mathrm{X}$.
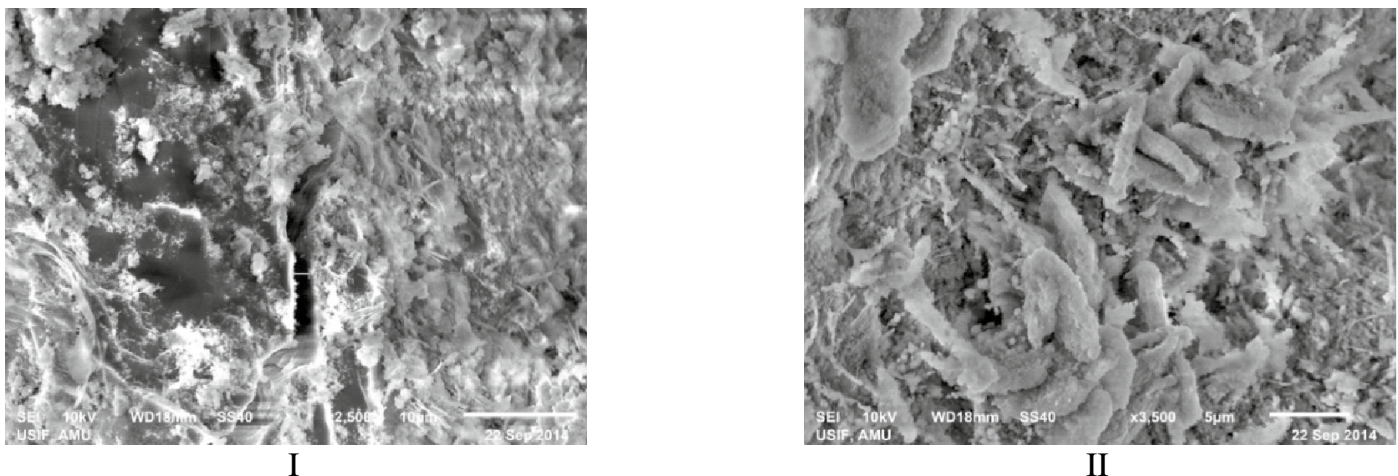

(e) SEM photomicrograph of concrete heated up to $800^{\circ} \mathrm{C}$, showing micro-cracks (I) seen at $2500 \mathrm{X}$ and vermicular growth of calcium hydroxide phase (II) seen at $3500 \mathrm{X}$.

Fig. 9 (continued)

during heating at elevated temperatures was studied. Different microtextures and development of microcracks with micropores at high magnifications. It has been found that the development of microcracks and pores, increases and becomes more pervasive with increase in temperature. The mineral phases of aggregate do not show any change because they form at temperatures up to $1000^{\circ} \mathrm{C}$. Not much difference was found in the mortar matrix at $200^{\circ} \mathrm{C}$ and $400^{\circ} \mathrm{C}$ as depicted in Fig. 9b. Though, samples heated at $600{ }^{\circ} \mathrm{C}$ and $800^{\circ} \mathrm{C}$ show open and disruptive intra mineral space, with pervasive development of micro-cracks as shown in Fig. 9c, d respectively. The growth of the $\mathrm{C}-\mathrm{H}-\mathrm{S}$ phase in the cement-sand matrix takes place during hydration and setting of mortar or concrete due to the intermixing of these crystals. In the study, these phases were recognized based on their micro-morphology in the concrete cast at ambient temperatures. It has been found that these crystals grow in size in concrete subjected to heating at $200,400,600$, and $800^{\circ} \mathrm{C}$. The observations made during the micro-study of concrete samples suggest that excessive heating on the concrete result in further growth of
$\mathrm{C}-\mathrm{S}-\mathrm{H}$ phases which create internal micro stresses leading to the development of micro-cracks which widens, resulting into failure of concrete (Fig. 9e). The breakdown of concrete at higher temperatures was off course attributed to disintegration and decomposition but the reason is that with heat when crystals start growing, which the case with all minerals is in natural and artificial mineralogy. It is the growth of mineral-crystals that start "shoving and pushing" the other mineral-crystal, leading to the development of open pores and cracks.

\section{Conclusions}

In the present research, the effort has been given to observe the behavior of RC specimens after heating at elevated temperatures both experimentally as well as numerically. The following conclusions have been drawn from the present:

\section{SN Applied Sciences}


- The load carrying capacity of the RC cylinder decreases with an increase in temperature, but the reserved load carrying capacity of the RC cylinder is $62 \%$ after heating at $400{ }^{\circ} \mathrm{C}$ temperatures.

- A significant loss in compressive strength has been observed beyond $600{ }^{\circ} \mathrm{C}$ and therefore the strength of RC members cannot be considered in the design of concrete structures.

- Closely spaced lateral ties are likely to protect early failure in RC specimens at elevated temperatures as only surface spalling has been observed at a temperature of $800^{\circ} \mathrm{C}$.

- Temperature contours at $200,400,600$, and $800{ }^{\circ} \mathrm{C}$ after $3 \mathrm{~h}$ heating duration in the finite element model is in close agreement with the core temperature of the respective $\mathrm{RC}$ specimens in the furnace after the same $3 \mathrm{~h}$ holding period of exposure. Thermal strains obtained from finite element analysis of RC specimens are also in close agreement with the experimentally observed values at all temperatures.

- Finite element analysis of RC specimens shows high values of thermal stress up to $600^{\circ} \mathrm{C}$ which decreases at $800^{\circ} \mathrm{C}$ because of the development of surface cracks. At higher temperatures beyond $800^{\circ} \mathrm{C}$, it may lead to spalling of cover concrete and thus will affect the structural integrity of the RC members.

- From the SEM study, it can be observed that the development of microcracks and pores increases and become more pervasive with increase in temperature. Further, the SEM reveals insufficient growth in the size of $\mathrm{C}-\mathrm{S}-\mathrm{H}$ phases due to heating resulting in the development of internal stresses, which cause failure in high grade concrete.

\section{Compliance with ethical standards}

Conflict of interest On behalf of all authors, the corresponding author states that there is no conflict of interest.

\section{References}

1. Raut N, Kodur V (2011) Computer model for predicting the fire response of reinforced concrete columns. ACI Spec Pub 279:146. https://www.concrete.org/publications/internationalconcret eabstractsportal $/ \mathrm{m} /$ details/id/51682973

2. Al-Salloum YA, Elsanadedy HM, Abadel AA (2011) Behavior of FRP-confined concrete after high temperature exposure. Constr Build Mater 25(2):838-850. https://doi.org/10.1016/j.conbu ildmat.2010.06.103

3. Kumar V, Sharma UK, Singh B, Bhargava (2012) Residual postfire behaviour of pre-damaged confined concrete. World conference of earthquake engineering, 15WCEE, Lisbon, Portgal, September, 24-28. https://www.iitk.ac.in/nicee/wcee/artic le/WCEE2012_3981.pdf

4. Ramadoss P, Nagamani K (2013) Stress-strain behavior and toughness of high-performance steel fiber reinforced concrete in compression. Comput Concr 11(2):149-167. https://doi. org/10.12989/cac.2013.11.2.149

5. Wu Y, Wu B (2014) Residual compressive strength and freezethaw resistance of ordinary concrete after high temperature. Constr Build Mater 54:596-604. https://doi.org/10.1016/j.conbu ildmat.2013.12.089

6. Su H, Xu J, Ren W (2014) Experimental study on the dynamic compressive mechanical properties of concrete at elevated temperature. Mater Des 56:579-588. https://doi.org/10.1016/j. matdes.2013.11.024

7. Ma Q, Guo R, Zhao Z, Lin Z, He K (2015) Mechanical properties of concrete at high temperature-a review. Constr Build Mater 93:371-383. https://doi.org/10.1016/j.conbuildmat.2015.05.131

8. Khan MS, Abbas H (2016) Performance of concrete subjected to elevated temperature. Eur J Environ Civ Eng 19(6):1825-1831. https://doi.org/10.1080/19648189.2015.1053152

9. Lee YW, Kim GY, Gucunski N, Choe GC, Yoon MH (2016) Thermal strain behavior and strength degradation of ultra-highstrength-concrete. Mater Struct 49(8):3411-3421. https://doi. org/10.1617/s11527-015-0728-x

10. Yermak N, Pliva P, Beaucour AL, Simon A, Noumowe A (2017) Influence of steel and/or polypropylene fibres on the behaviour of concrete at high temperature: spalling, transfer and mechanical properties. Constr Build Mater 132:240-250. https ://doi.org/10.1016/j.conbuildmat.2016.11.120

11. Zahid MM, Bakar BA, Nazri FM (2019) Behaviour of post heated reinforced concrete columns. In: IOP conference series: earth and environmental science $2019 \mathrm{Feb}$ (vol 244, no 1, p 012006). IOP Publishing. https://doi.org/10.1088/1755-1315/244/1/01200 6

12. Ibrahimbegovic A, Boulkertous A, Davenne L, Muhasilovic $M$, Pokrklic A (2010) On modeling of fire resistance tests on concrete and reinforced-concrete structures. Comput Concr 7(4):285-301. https://doi.org/10.12989/cac.2010.7.4.285

13. Al-Salloum $\mathrm{YA}$, Shah $\mathrm{AA}, \mathrm{Abbas} \mathrm{H}$, Alsayed $\mathrm{SH}$, Almusallam $\mathrm{TH}$, Al-Haddad (2012) Prediction of compressive strength of concrete using neural networks. Comput Concr 10(2):197-217. https://doi.org/10.12989/cac.2012.10.2.197

14. Shrestha R, Smith ST, Samali B (2013) Finite element modelling of FRP-strengthened RC beam-column connections with ANSYS. Comput Concr 11(1):1-20. https://doi.org/10.12989/ cac.2013.11.1.001

15. Rashid RSM, Aboutaha RS (2014) Analytical model for CFRP strengthened circular RC column under elevated temperature. Comput Concr 13(4):517-529. https://doi.org/10.12989/ cac.2014.13.4.517

16. Mohamed AAE (2014) Structural analysis for concrete columns subjected to temperature. CORVINIENSIS-Bulletin of Engineering, Tome VII Fascicule 2, April-June, 70-81. http://acta.fih.upt. ro/pdf/2014-2/ACTA-2014-2-12.pdf

17. Wu H, Wang $Y$ (2015) Multiscale modeling for compressive strength of concrete columns with circular cross-section. Comput Concr 15(6):865-878. https://doi.org/10.12989/ cac.2015.15.6.865

18. Buch SH, Sharma UK (2019) Fire resistance of eccentrically loaded reinforced concrete columns. Fire Technol 55(5):15171552. https://doi.org/10.1007/s10694-019-00823-x

19. Buch SH, Sharma UK (2019) Empirical model for determining fire resistance of Reinforced Concrete columns. Constr Build Mater 20(225):838-852. https://doi.org/10.1016/j.conbuildma t.2019.07.183 
20. Chinthapalli HK, Agarwal A (2020) Effect of confining reinforcement on fire behavior of reinforced concrete columns: experimental and numerical study. J Struct Eng 146(6):04020084. https ://doi.org/10.1061/(ASCE)ST.1943-541X.0002617

21. IS 4031 (Part 1 to 15) (1999) Methods of physical tests for hydraulic cement. Bureau of Indian Standards, New Delhi

22. IS 15388 (2003) Indian standard of silica fume- specifications. Bureau of Indian Standards, New Delhi

23. IS 383 (1970) Indian standard specifications for coarse and fine aggregates from natural sources for concrete. Bureau of Indian Standards, New Delhi

24. IS 1786 (1985) Indian standard specifications for high strength deformed steel bars and wires for concrete reinforcement. Bureau of Indian Standard, New Delhi

25. IS 456 (2000) Code of practice for plain and reinforced concrete (third revision). Bureau of Indian Standards, New Delhi

26. IS 1642 (1989) Indian standard fire safety of buildings (general): details of construction-code of practice. Bureau of Indian Standard, New Delhi
27. IS 516 (1959) Methods of tests for strength of concrete. Bureau of Indian Standards, New Delhi

28. Hedayati M, Sofi M, Mendis PA, Ngo T (2015) A comprehensive review of spalling and fire performance of concrete members. Electron J Struct Eng 15:8-34. http://www.ejse.org/Archives/ Fulltext/2015-2/2015-2-2.pdf

29. Kodur V (2014) Properties of concrete at elevated temperatures. Hindawi Publishing Corporation, ISRN Civil Engineering. 2014 March 13; Volume 2014, Article ID 468510. https://doi. org/10.1155/2014/468510

Publisher's Note Springer Nature remains neutral with regard to jurisdictional claims in published maps and institutional affiliations. 